AGRICULTURE AND BIOLOGY JOURNAL OF NORTH AMERICA

ISSN Print: 2151-7517, ISSN Online: 2151-7525, doi:10.5251/abjna.2012.3.4.145.149

(C) 2012, ScienceHuß, http://www.scihub.org/ABJNA

\title{
The Effect of Phosphate Fertilizer on Heavy Metal in Soils and Amaranthus Caudatus
}

\author{
Thomas, E. Y, Omueti, J. A.I and Ogundayomi, O \\ Agronomy Dept, University of Ibadan, Nigeria.
}

\begin{abstract}
The study examines the effect of Phosphate fertilizer on heavy metals in soils and Amaranthus Caudatus. Pot experiment was carried out to assess the effect of Phosphate fertilizer on heavy metal uptake by Amaranthus Caudatus. Single Super Phosphate fertilizer (SSP) was applied at the rates of $0,60,80$ and $100 \mathrm{~kg}$ fertilizer/ha and replicated three times in a completely randomized design. The parameters measured were plant height, number of leaves, and heavy metals $(\mathrm{Cu}, \mathrm{Zn}, \mathrm{Cd}, \mathrm{Pb}$ and $\mathrm{Ni}$ ) concentration in the soil before and after the experiment, heavy metal concentration in the stem and roots of the vegetable used were also measured. The results of this experiment shows that there were no significant difference in plant height and number of leaves among the treatments considered, but the number of leaves increases from the second to the fourth weeks after sowing before it begin to decline. Only $\mathrm{Cu}, \mathrm{Zn}$ and $\mathrm{Cd}$ were taken up by the root and stems of the vegetable with $\mathrm{Zn}$ having the highest concentration at $100 \mathrm{~kg} / \mathrm{ha}$ and $80 \mathrm{~kg} / \mathrm{ha}$ level of application for stem and root respectively. The concentrations of all the metals $(\mathrm{Cu}, \mathrm{Zn}, \mathrm{Pb}$ and $\mathrm{Cd})$ increases in the soil after the experiment except for Nickel. Increase in the concentration of Zinc in the soil was more pronounced than other metals. It is therefore recommended that Phosphate fertilizer should be analyzed to determine the concentration of heavy metals before its application to the soil for plant growth.
\end{abstract}

Keywords: Heavy metals, Phytoremediation, Amaranthus Caudatus

\section{INTRODUCTION}

Heavy metals are currently of more environmental concern to scholars in various fields owing to its associated effects on humans and the environment. They are harmful to humans and animals as they tend to bio-accumulate in the food chain. Activities such as mining and smelting of metal ores, industrial emissions and applications of insecticides and fertilizers have all contributed to elevated levels of heavy metals in the environment (Alloway; 1990). Although, heavy metals occurs naturally in low concentration in soil, but they are considered as soil contaminants due to their widespread occurrence, acute and chronic toxicity (Das, et al,. 1997). Soil contamination by heavy metals is one of the most serious ecological problems all over the world. These metals include; cadmium (Cd), lead (Pb), zinc ( $\mathrm{Zn})$, copper $(\mathrm{Cu})$, nickel $(\mathrm{Ni})$, mercury $(\mathrm{Hg})$, and the metalloid arsenic (As). When plants accumulate metals, they can be ingested by animals, thus creating the potential for toxic effects at higher trophic level (Crowder, 1991). The exposure to acute $\mathrm{Cd}$ and $\mathrm{Zn}$ concentrations often results in gastrointestinal and respiratory damage, as well as damages to heart, brain, and kidney (Friberg, et al., 1986).
Amaranthus caudatus belong to the amaranthaceae family the leaves and seeds are edible and nutritious like any other amaranth. Amaranthus caudatus used in this study is a grain and ornamental vegetable crop with quick growth and great biomass. Phosphorus fertilizers are among the sources of heavy inputs into agricultural activities Superphosphate fertilizers contain in addition to nutrient elements trace metal impurities like $\mathrm{Cd}, \mathrm{Pb}$ or $\mathrm{Hg}$ ( Oyedele et al, 2006 ,Zhang and Shan, 2001 , Nicholson and Jones, 1994) ). According to Mortvedt and Beaton (1995), on the average phosphate rock contain 11, 25, 1888, 32, 10 and 239mgkg-1 of As, $\mathrm{Cd}, \mathrm{Cr}, \mathrm{Cu}, \mathrm{Pb}$ and $\mathrm{Zn}$, respectively. Therefore the objective of this study is to evaluate the effect of phosphorus fertilizer on heavy metal accumulation in Amaranth caudatus and soil.

\section{MATERIALS AND METHODS}

Description of Experimental Site: This study was carried out using pot experiment planted within the crop garden of Agronomy Department of the University of Ibadan, Ibadan, and Oyo State, Nigeria. Ibadan is in the tropical rainforest of south west Nigeria between latitudes $7^{\circ} 15^{\prime} \mathrm{N}$ to $7^{\circ} 30^{\prime} \mathrm{N}$ and longitude $3^{\circ} 45^{\prime} \mathrm{E}$ 
Sample Collection: The soil sample used for this experiment was collected from Bodija dump site located at Kara in Bodija. The seeds of amaranthus caudatus were obtained from the department seed store.

Basic physico-chemical soil characteristics: Particle size distribution was determined by Bouyoucus hydrometer method as cited by Tel and Hargaty (1991) using sodium hexametaphosphate (Calgon) as the dispersing agent.

Soil $\mathrm{pH}$ was determined using distilled water and potassium chloride $(\mathrm{KCl})$ with a mobile $\mathrm{pH}$ meter. Organic carbon was analyzed by the dichromate wet oxidation method. Total nitrogen was determined by macro Kjedahl method. Available phosphorus was determined by the Bray $\mathrm{P} 1\left(0.03 \mathrm{~m} \mathrm{~N} \mathrm{NH}_{4} \mathrm{~F}+0.02 \mathrm{~m}\right.$ $\mathrm{HCl}$ ) solution and determined Calorimetrically by the molybdenum blue method. Micronutrients, (Mn, Fe, $\mathrm{Cu}$ and $\mathrm{Zn}$ ) were extracted with Melich solution and determined with Atomic absorption spectrophotometer (AAS). The exchangeable acidity was determined using titration method. The total heavy metal content $(\mathrm{Cd}, \mathrm{Pb}, \mathrm{Ni}, \mathrm{Zn}$ and $\mathrm{Cu}$ ) was also determined with the AAS. Exchangeable bases, were leached using $1 \mathrm{~N} \mathrm{NH}_{4}$ and were determined by AAS.

Experimental Design: Three seeds of test crop used Amarauthus caudatus was sown directly into the pots and was later tinned down to 2 plants per pot given a total of 32 plants in all. Each pot contained $1 \mathrm{~kg}$ of soil. The experiment consists of four treatments (Single superphosphate fertilizer) in the following rates; $0,60,80$ and $100 \mathrm{~kg} / \mathrm{ha}$, replicated five times each given a total of 20 replicates in a randomized complete block design. Plant height and number of leaves were ascertained.

Plant and Soil Analysis: The vegetables were harvested at 5 weeks after sowing and washed with de-ionised water, separated into shoot and root and oven dried at $65^{\circ} \mathrm{C}$ before wet drying and grinding. $0.5 \mathrm{~g}$ was weighed from each sample, digested in a mixture of concentrated $\mathrm{HNO}_{3}$ and $\mathrm{HClO}_{4}(4: 1$, by volume ) and made up to mark $(25 \mathrm{ml})$ with distill water for heavy metal analysis $(\mathrm{Cd}, \mathrm{Pb}, \mathrm{Ni}, \mathrm{Zn}$ and $\mathrm{Cu})$ through AAS.

Soil samples were collected randomly after the termination of the experiment, air dried and sieved with $0.5 \mathrm{~mm}$ sieve. $0.5 \mathrm{~g}$ of soil was taken from each treatment sample and digested using acid mixture made up to $25 \mathrm{ml}$ with distilled water for heavy metal analysis. The heavy metals analysed are $\mathrm{Cd}, \mathrm{Pb}, \mathrm{Ni}$, $\mathrm{Zn}$ and $\mathrm{Cu}$.

Statistical Analysis: The results collected from the experiment were subjected to analysis of variance (ANOVA) and the means compared using least significant difference (LSD).

Table 1: Basic Physico-Chemical Soil Characteristics, Total Heavy Metal Contents in the Experimental Soil

\begin{tabular}{|l|l} 
Parameters & \\
\hline $\mathrm{pH}$ in $\mathrm{H}_{2} \mathrm{O}$ & \\
\hline$\%$ Organic carbon & 0 \\
\hline Total nitrogen & \\
\hline Available phosphorus & \\
\hline Exchangeable bases $\left(\mathrm{Cmolkg}^{-1}\right) \mathrm{K}$ & \\
\hline $\mathrm{Na}$ & \\
\hline $\mathrm{Mg}$ & \\
\hline $\mathrm{Ca}$ & \\
\hline Extractable micronutrients $\left(\mathrm{mgkg}^{-1}\right)$ & \\
\hline $\mathrm{Mn}$ & \\
\hline $\mathrm{Fe}$ & \\
\hline $\mathrm{Heavy}$ metals $\left(\mathrm{mgkg}^{-1}\right)$ & \\
\hline $\mathrm{Cu}$ & \\
\hline $\mathrm{Zn}$ & \\
\hline $\mathrm{Cd}$ & \\
\hline $\mathrm{Pb}$ & \\
\hline $\mathrm{Ni}$ & \\
\hline Textural class & \\
\hline
\end{tabular}

\section{RESULT AND DISCUSSION}

Physicochemical properties of soil: The result of the soil analysis carried out (Table 1) shows that the soil is an alkaline soil, low in organic matter and total
Values

9.1

0.114

0.12

$11.9\left(\mathrm{mgkg}^{-1}\right.$

10.18

4.27

9.06

20.06

80.3

54.9

5.81

499.2

1.05

55.5

103.2

Sandy soil

nitrogen but high in available phosphorus. The soil is high in $\mathrm{Ni}$ and $\mathrm{Zn}$ but low in $\mathrm{Pb}, \mathrm{Cd}$ and $\mathrm{Cu}$ with moderate concentration of other nutrient elements. 
Effect of different levels of phosphate fertilizer on the plant height: Result from the table 2 shows that treatment 1 and 4 (0 and $100 \mathrm{~kg} /$ ha fertilizer) at 2 nd and the $3^{\text {rd }}$ weeks after sowing with 10.50 and 11.47 gave the highest mean values of 3.67 and 3.77 respectively. Conversely, treatment $4(100 \mathrm{~kg} / \mathrm{ha})$ at the 5th weeks after sowing has the highest mean value of 30.4. However, Analysis of variance(ANOVA) revealed no significant difference among all the treatments considered on plant height.

Number of Leaves: At the $2^{\text {nd }}$ and $4^{\text {th }}$ weeks after planting, treatment $1(0 \mathrm{~kg} / \mathrm{ha})$ has mean values of 6.0 and 13.75 respectively. This gives best performance in terms of leaf production as shown in Table 3. However, there was no significant difference in the number of leaves in the different weeks after sowing but a general decrease in the number of leaves was observed at the $5^{\text {th }}$ week after sowing, this was due to senescence.

Heavy metals uptake in the stem of Amaranthus caudatus: Figure 1 shows the concentration of $\mathrm{Cu}$, $\mathrm{Zn}, \mathrm{Cd}, \mathrm{Pb}$ and $\mathrm{Ni}$ in the stem of Amaranthus caudatus under different levels of phosphate fertilizer application. Zinc concentration in the stem concentration was highest in all the treatment compared with the concentrations of the other metals and the highest concentration $(105.75 \mathrm{mg} / \mathrm{kg})$ was recorded under treatment $4(100 \mathrm{~kg} / \mathrm{ha})$ though the initial concentration was $499.2 \mathrm{mg} / \mathrm{kg}$. This was closely followed by $\mathrm{Cu}$, which shows an increase in its concentration in the stem for all the fertilizer levels when compared with the initial concentration in the soil before planting $(5.8 \mathrm{mg} / \mathrm{kg})$ to $7.05,6.45,7.06$ and $8.9 \mathrm{mg} / \mathrm{kg}$ respectively after harvesting, this support the findings of Lafuente et al(2008) . The concentration of $\mathrm{Cd}$ in the stem was high compared with its initial concentration in the soil. $\mathrm{Pb}$ and $\mathrm{Ni}$ were not detected except $5.55 \mathrm{mg} / \mathrm{kg}$ under $80 \mathrm{~kg} / \mathrm{ha}$ fertilizer used. $\mathrm{Pb}$ has a greater retention capacity in soil when compared with other metals (Lafuente et al, 2008).

Heavy metals in the root: The concentration of $\mathrm{Cu}$, $\mathrm{Zn}, \mathrm{Cd}, \mathrm{Pb}$ and $\mathrm{Ni}$ in the root of $A$ caudatus is represented in Figure 2 The same trend was observed as it is in figure 1. Zinc uptake (92.15) in the root was highest in treatment $3(80 \mathrm{~kg} / \mathrm{ha})$ compared to the other metal uptake, closely followed by $\mathrm{Cu}$ also with its highest concentration in treatment $3(80 \mathrm{~kg} / \mathrm{ha})$. $\mathrm{Pb}$ and Ni were not detected.

Table 2: Effect of different levels of phosphate fertilizer on the plant height $(\mathrm{cm})$ of $A$. caudatus

\begin{tabular}{|l|c|c|c|c|}
\hline \multirow{2}{*}{ Treatments } & \multicolumn{4}{|c|}{ Weeks After Sowing } \\
\cline { 2 - 5 } & $\mathbf{2}$ & $\mathbf{3}$ & $\mathbf{4}$ & $\mathbf{5}$ \\
\hline $0 \mathrm{~kg} / \mathrm{ha}$ & 3.67 & 10.50 & 15.30 & 29.2 \\
\hline $60 \mathrm{~kg} / \mathrm{ha}$ & 3.23 & 9.57 & 19.90 & 20.4 \\
\hline $80 \mathrm{~kg} / \mathrm{ha}$ & 3.08 & 9.93 & 19.48 & 26.6 \\
\hline $100 \mathrm{~kg} / \mathrm{ha}$ & 3.77 & 11.47 & 4.779 & 30.4 \\
\hline LSD & 0.915 & 2.173 & $\mathrm{NS}$ & 9.93 \\
\hline
\end{tabular}

LSD: Least Significant Difference, NS: Not Significant

Table 3: Effect of different levels of phosphate fertilizer on the number of leaves produced by Amaranthus caudatus

\begin{tabular}{|c|c|c|c|c|}
\hline \multirow{2}{*}{ Treatment } & \multicolumn{4}{|c|}{ Weeks After Sowing } \\
\cline { 2 - 5 } & $\mathbf{2}$ & $\mathbf{3}$ & $\mathbf{4}$ & $\mathbf{5}$ \\
\hline $0 \mathrm{~kg} / \mathrm{ha}$ & 6.0 & 10.25 & 13.75 & 12.25 \\
\hline $60 \mathrm{~kg} / \mathrm{ha}$ & 5.75 & 8.75 & 11.50 & 11.00 \\
\hline $80 \mathrm{~kg} / \mathrm{ha}$ & 5.75 & 10.25 & 11.50 & 12.50 \\
\hline $100 \mathrm{~kg} / \mathrm{ha}$ & 5.75 & 11.00 & 2.933 & 11.00 \\
\hline LSD & 0.667 & 2.173 & $\mathrm{NS}$ & 3.137 \\
\hline
\end{tabular}

LSD: Least Significant Difference, NS: Not Significant

Table 4: Effect of different levels of phosphate fertilizer on heavy metal accumulation in the soil after the experiment

\begin{tabular}{|l|l|c|c|c|c|}
\hline \multirow{2}{*}{ Treatment } & \multicolumn{5}{|c|}{ Heavy Metals $\mathbf{m g k g}^{-1}$ ) } \\
\cline { 2 - 6 } & $\mathbf{C u}$ & $\mathbf{Z n}$ & $\mathbf{C d}$ & $\mathbf{P b}$ & $\mathbf{N i}$ \\
\hline $0 \mathrm{~kg} / \mathrm{ha}$ & 74.20 & 2062 & 2.35 & 55.5 & 24.8 \\
\hline $60 \mathrm{~kg} / \mathrm{ha}$ & 70.55 & 2158 & 6.60 & 65.5 & 26.7 \\
\hline $80 \mathrm{~kg} / \mathrm{ha}$ & 161.50 & 2208 & 1.15 & 91.5 & 23.6 \\
\hline $100 \mathrm{~kg} / \mathrm{ha}$ & 73.20 & 2638 & 1.05 & 86.5 & 29.8 \\
\hline
\end{tabular}


Agric. Biol. J. N. Am., 2012, 3(4): 145-149

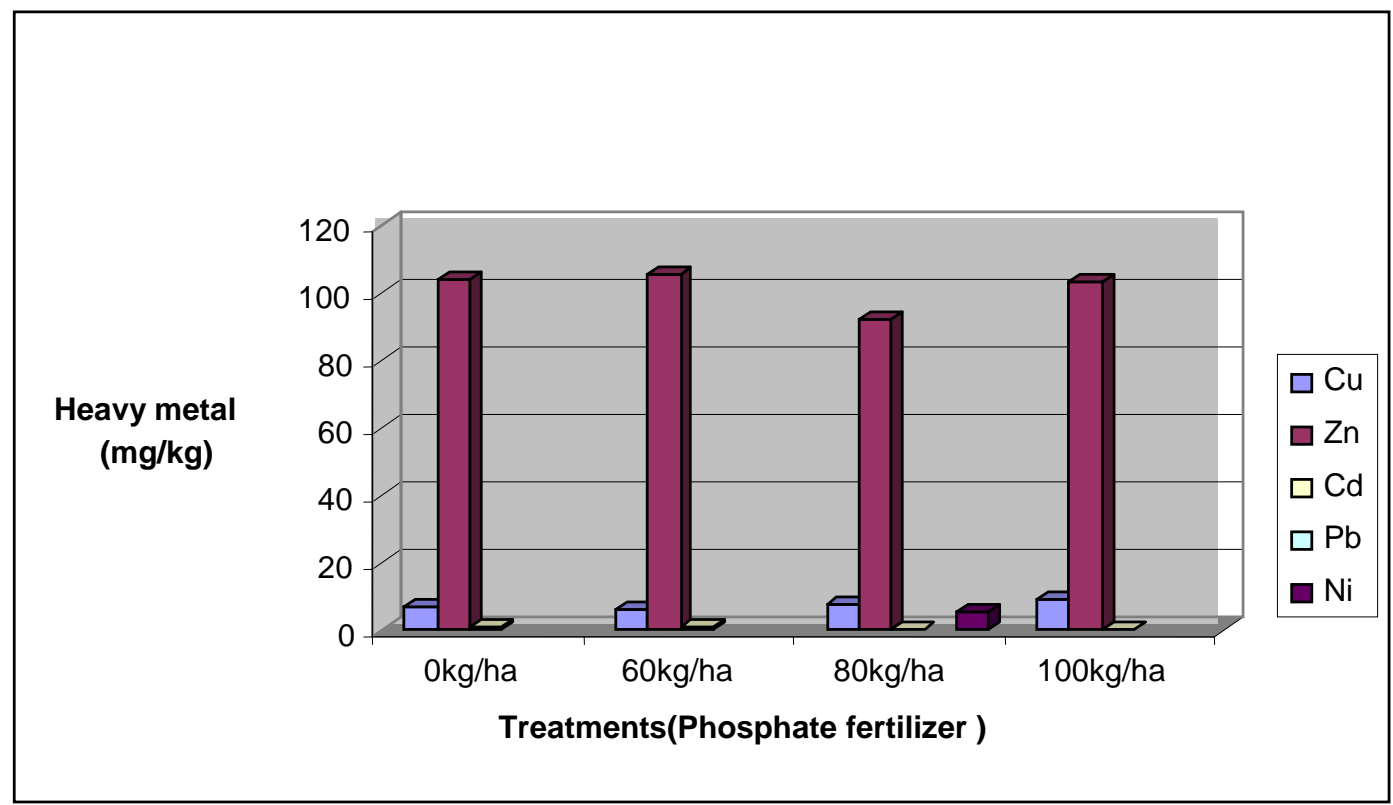

Fig 1. Effect of phosphorus fertilizer on heavy metal uptake in the stem of Amaranthus Caudatus plant

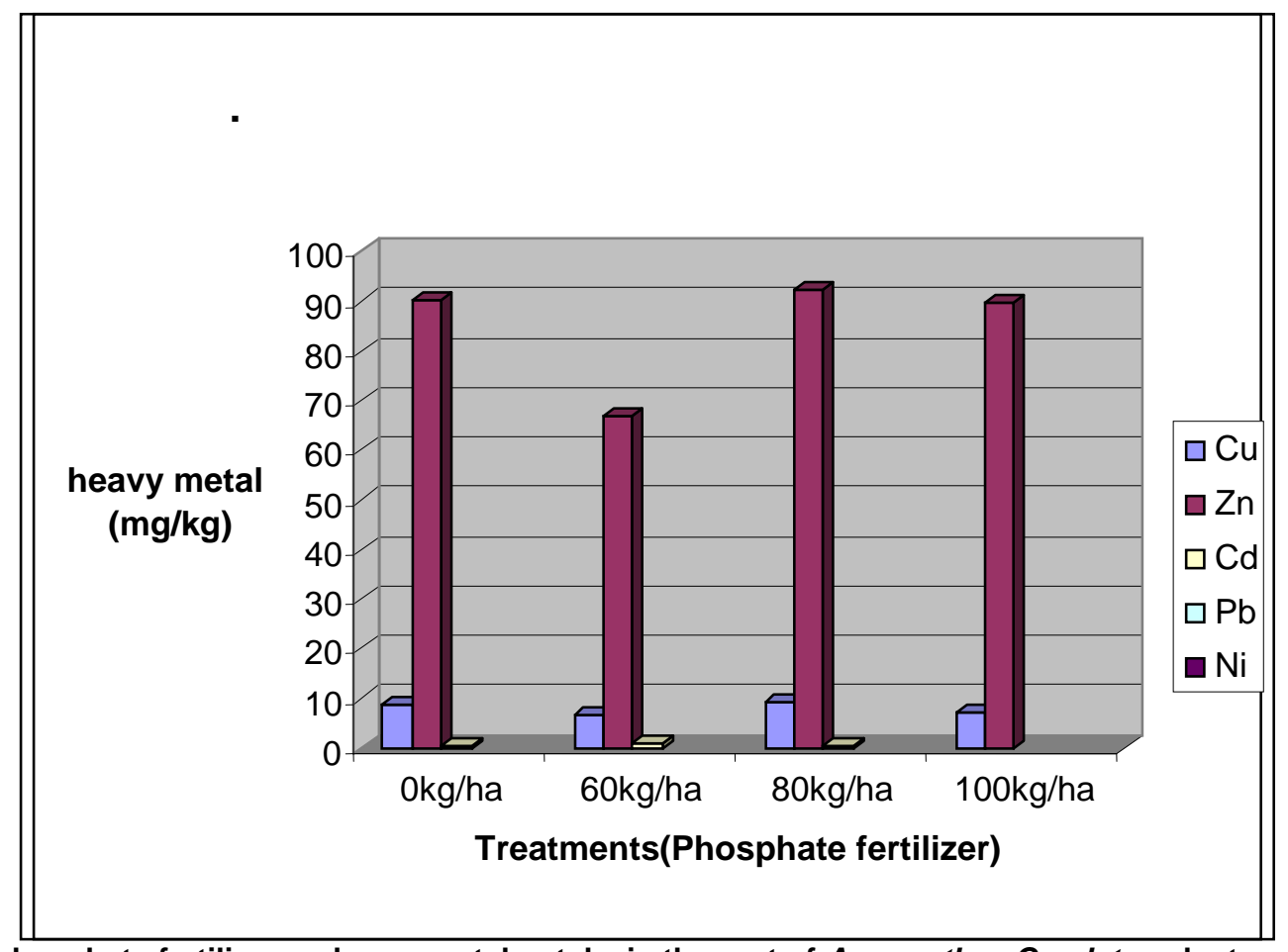

Fig 2. Effect of phosphate fertilizer on heavy metal uptake in the root of Amaranthus Caudatus plant

Heavy Metals In The Soil After Harvest: The concentration of heavy metals $(\mathrm{Cu}, \mathrm{Zn}, \mathrm{Cd}, \mathrm{Pb}$ and $\mathrm{Ni})$ in the soil after the experiment is shown on Table 4. The increase in the concentration of the heavy metals in the soil after the experiment shows that phosphate fertilizers contribute greatly to heavy metal content in soils. This is consistent with the findings of Oyedele et al., (2006). Cu, Zn, Cd and Pb show a 
high concentration in the soil after the experiment at all treatment levels. $\mathrm{Cu}$ and $\mathrm{Zn}$ had over $400 \%$ increment, $\mathrm{Cd}$ increased by over $100 \%$ and a little increase in $\mathrm{Pb}$ content was recorded this result agrees with the findings of Mirela et al( 2008) De Matos et al (2001) which says that $\mathrm{Pb}$ has the highest value of retardation factors which shows that it is highly immobilized in the soils also Alloway, (1990) reported that the soil is an important sink for heavy metals. Zinc concentration increased with increase in fertilizer level to further confirm that $\mathrm{Zn}$ is mobile.This support the assertions of Vaněk et al, .2005 that Zinc and Cadmium are highly mobile in the soil.

\section{CONCLUSION AND RECOMMENDATION}

The result of this experiment shows that different levels of phosphate fertilizer application have no significant effect on the plant height and number of leaves of Amaranthus caudatus. From the result $A$ caudatus is best harvested for fresh consumption as vegetable at four weeks after sowing because it gives the highest number of leaves at this point

This experiment shows that heavy metals concentration is highest in the soil compared to the stem and root of the vegetable used, the concentration of $\mathrm{Ni}$ in the stem and root of the vegetable shows that plant rarely take up $\mathrm{Ni}$ from the soil. Only $\mathrm{Zn}, \mathrm{Cu}$ and $\mathrm{Cd}$ shows an increase in the soil concentration with an increase in levels of phosphate fertilizer applied we can safely conclude from this result that heavy metal accumulation in the soil does not depend on levels of phosphate fertilizer but on the levels of heavy metal impurities in the phosphate rock used for the fertilizer production

The fairly high uptake of $\mathrm{Cu}, \mathrm{Zn}$ and $\mathrm{Cd}$ by the plant roots and stems under $0 \mathrm{~kg} / \mathrm{ha}$ phosphate fertilizer shows that Amaranthus caudatus has the potential of being used to clean up heavy metal contaminated soils and that only uncontaminated soils should be used to produce the vegetable.

\section{REFERENCES}

Alloway, B.J (1990): Toxic Metals in soil-plant systems. John Wiley and Sons, Chichester.
Das, P., Samantaray. S., and Ront, G.R.( 1997). Studies on Cadmium toxicity in plants: a review. Environ. Pollut. 98.

De Matos , A.T , Funtes ,M.P. F, Dacosta, M.A , Martinez , M.A (2001). Mobility of heavy metal as related to soil chemical and mineralogical characteristics of Brazilian soils. Published by environmental pollution III (2001) 429-435).

Frieberg,L, Ellinder, C.G and Kjellstrom,T(1992) "Cadmium - environmental aspects" Environmental health criteria 134. Geneva: World Health Organisation.( 1992).

Lafuente ,A.L, Gonzalez,C, Quintana, J.R; Vazquez and Romero, A (2008) Mobility of heavy metals in poorly developed carbonate soils in the mediteramein region. Published in Geoderma (145) 238-244.

Mirela M., Cecilia R., Erika L., Marin S., Bela A., Emil C, (2008): Heavy metals availability for plants in a mining area from North-Western Romania .A publication by International soil Conservation Organization .

Mortvedt,J Mays, D.A and Osborn, G(1981) "Uptake by wheat of cadmium and other heavy metal contaminants in phosphate fertilizers", J Environ. Quality, 10,193-197 (1981).

Nicholson, F.A and Jones, K. C(1994) "Effect of phosphate fertilizers and atmospheric deposition on long-term changes in cadmium content of soils and crops", Environ. Sci. Technol. 28, 2170-2175 (1994).

Oyedele, D.J. Asonugho, C., and Awotoye, O.O.( 2006): Heavy metals in soil and accumulation by edible vegetables after phosphate fertilizer application. Electronic Journal of Environmental, Agricultural and Food Chemistry 5(4) 1446-1453).

Singh,B.T (1994)"Trace Element availability to plants in agricultural soils with special emphasis on fertilizer inputs", Environ Rev. 2,133-146 (1994).

Vaněk,A. Borûvka, L. Drábek,O. Mihaljevič, M, Komáre;(2005) .Mobility of Lead,Zinc and Cadmium in alluvial soils heavily polluted by smeling indusry. Plant Soil Environment.,51,2005(7); 316-321.

Williams , C. H and D.J. David, D.J,(1973) "The effect of superphosphate on the cadmium content of soils and plants", Aust. J. Res. 11, 43-56 (1973).

Zhang, S and Shan, $X(2011)$ "Speciation of rare earth elements in soil and accumulation by wheat with rare earth fertilizer application", Environ. Pollution 112, 395405 (2001). 